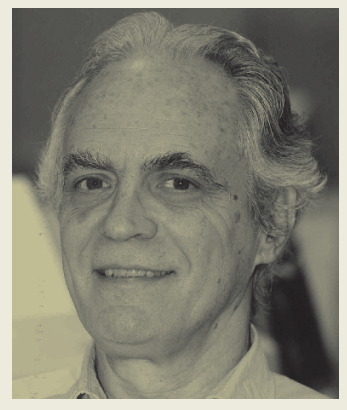

\title{
A PRIVATIZAÇÃO NÃO VAI SALVAR A PÁTRIA
}

"O governo gasta muito e gasta mal". Embora em parte verdadeira, a afirmação transformou-se em mantra dos defensores das privatizações. A ideia subjacente é que, passando para as mãos do setor privado (gastaria pouco e bem?), certas atividades reduziriam as despesas do governo. Eis aí a solução para o ajuste fiscal: privatizar, e com a mesma receita (ou até com a redução de impostos) alcançar o equilíbrio das contas públicas.

Trata-se, em grande medida, de uma ilusão. Podemos classificar as despesas do governo em três grupos. Em primeiro lugar estão aquelas relacionadas com o desperdício, decorrentes do empreguismo, de privilégios, de mordomias e de corrupção. São problemas difíceis de combater e mudar, mas um governo honesto e competente, com mandato popular obtido nas urnas, pode eliminar grande parte dessas despesas via puramente administrativa.

Um segundo grupo de gastos é respaldado por legislação constitucional ou infraconstitucional. Destaco o exemplo mais evidente das despesas previdenciárias. Sua redução depende de um corajoso enfrentamento de interesses corporativos. A mudança requer apoio robusto no Congresso, pois as alterações legais, por vezes, exigem maioria qualificada. Novamente, apesar das dificuldades, um governo honesto e competente com agenda específica e respaldo popular obtido nas urnas pode alcançar êxito.

Muitos dirão que, em um país como o nosso, as duas ações anteriores são inviáveis, quase impossíveis. Talvez tenham razão. Chamo apenas a atenção para o fato de que elas dependem exclusivamente da luta contra interesses de castas e grupos minoritários.
Um terceiro conjunto de despesas tem outra natureza. São as decorrentes dos serviços públicos brindados à população. Por diversas razões, o custo unitário desses serviços cresce com o aumento de sua oferta. Deseconomias de escala, diriam os economistas.

Maiores distâncias nas cidades causadas pela intensa urbanização constituem uma delas. Dois exemplos: 1) transportar uma pessoa por $10 \mathrm{~km}$ custa mais do que transportá-la por $5 \mathrm{~km}$, e a nova licitação do transporte por ônibus em São Paulo, incluindo veículos climatizados, tornará esse custo ainda maior; 2) a segurança hídrica para os habitantes da área metropolitana de São Paulo levou o governo do Estado a investir cerca de $\mathrm{R} \$ 2,2$ bilhões na transposição em reservatórios situados a cerca de $85 \mathrm{~km}$ de distância da cidade.

No caso da saúde, a origem do aumento de custos é outra. Os avanços da medicina - que merecem aplausos permitiram transformar doenças fatais em doenças crônicas. Mas os custos aumentaram duplamente: pela utilização de tecnologias mais caras (remédios, aparelhos etc.), geralmente controladas por empresas oligopolistas que não costumam reduzir preços por aumentos de produtividade, e porque as pessoas, vivendo mais, necessitam de atendimento por um período maior.

Incapazes de pagar por tais aumentos de custos, os governos têm deixado de fornecer serviços à população e/ou convivido com a decadência de sua qualidade. Solução mitigadora: investir no aumento de produtividade na construção desses serviços (por exemplo, com corredores de ônibus) ou depender menos deles (por exemplo, substituindo a medicina curativa pela preventiva). As privatizações não vão garantir que se marche nessa direção. 